$\mathbb{T}$ periodica polytechnica

Chemical Engineering $5 1 / 2 ( 2 0 0 7 ) 6 1 \longdiv { 6 6 }$

doi: 10.3311/pp.ch.2007-2.10

web: http://www.pp.bme.hu/ch

(c) Periodica Polytechnica 2007

RESEARCH ARTICLE

\section{Liquid-liquid extraction of chromium (VI) from sulfuric acid solutions using tri-n-dodecylamine/kerosene}

\author{
Jamal Stas
}

Received 2007-01-18

\begin{abstract}
Extraction of chromium(VI) from sulfuric acid solutions with tri-n-dodecylamine containing octanol-1 as a modifier in kerosene was investigated. All parameters influencing the extraction of chromium(VI) (time of agitation, concentrations of chromium(VI), sulfuric acid, tri-n-dodecylamine and temperature) were studied. The mathematical treatment of the obtained data enabled us to propose a mechanism of chromium(VI) extraction by tri-n-dodecylamine as follows:

$2 \overline{\mathrm{TDAHHSO}_{4}}+\mathrm{Cr}_{2} \mathrm{O}_{7}^{2-} \rightleftarrows \overline{(\mathrm{TDAH})_{2} \mathrm{Cr}_{2} \mathrm{O}_{7}}+2 \mathrm{HSO}_{4}^{-}$

The logarithm of the equilibrium constant of the extraction reaction was found to be 10.6. Stripping of more than $99 \%$ of chromium(VI) from the organic phase of tri-ndodecylamine/kerosene can be easily achieved in two stages using 0.05 M sodium carbonate solution.
\end{abstract}

The synergistic effect of tri-n-butylphosphate and tri-noctylphosphine oxide on the extraction of chromium(VI) were also studied.

\section{Keywords}

Extraction - Chromium(VI) · sulfuric acid · tri-ndodecylamine/kerosene.

\section{Acknowledgement}

The author wishes to thank Prof. I.Othman, Director General of Syrian Atomic Energy Commission (S.A.E.C) for support and encouragement and Prof. T. Yassin, head of Chemistry Department and Prof. A. Haj Said member of consultative committee at (S. A. E. C) for fruitful discussions, and Miss R. Haj Said for assistance with the experimental work and Mr. J. Abu Hilal for the determination of chromium (VI) by diphenylcarbazide method.

\section{Jamal Stas}

Department of Chemistry, Atomic Energy Commission,, P.O.Box 6091 Damascus, Syria

\section{Introduction}

It is well known that chromium (VI) is highly toxic, and carcinogenic metal, and can be encountered in the environment, specially as result of human activities in many industries (pigments, steel works, electroplating, leather tanning, wood treatment, etc) which generate a huge amount of wastewater [1, 2]. Therefore, the need of an efficient separation technology is extremely needed to prevent the migration of $\mathrm{Cr}$ (VI) into the ground water which is a vital source of our existence in this earth. Liquid-Liquid extraction technique is one of the best and suitable methods which can be used for this purpose.

The extraction of chromium(VI) from sulfuric acid by trin-octylamine $(\overline{T O A})$ diluted in different diluents such as $\left(\overline{\mathrm{C}_{6} \mathrm{H}_{6}}, \overline{\mathrm{C}_{6} \mathrm{H}_{5} \mathrm{NO}_{2}}, \overline{\mathrm{CCl}_{4}}\right)$ has been investigated by Deptula [3], he found that the mechanism of chromium(VI) extraction by $\overline{T O A}$ depending on the dilution and maximum saturation metal can be described as follows:

$$
\begin{array}{r}
\mathrm{Cr}_{2} \mathrm{O}_{7}^{2-}+2 \overline{\mathrm{R}_{3} \mathrm{NH}^{+}} \rightleftarrows \overline{\left(\mathrm{R}_{3} \mathrm{NH}\right)_{2} \mathrm{Cr}_{2} \mathrm{O}_{7}} \\
\mathrm{HCr}_{2} \mathrm{O}_{7}^{-}+\overline{\mathrm{R}_{3} \mathrm{NH}^{+}} \rightleftarrows \overline{\mathrm{R}_{3} \mathrm{NH}_{2} \mathrm{Cr}_{2} \mathrm{O}_{7}}
\end{array}
$$

where: The upper line refers to the organic phase.

In another study Fedorov and Zhadanov [4] reported that trioctylamine extracts chromium (VI) as $\mathrm{CrO}_{4}^{2-}$ from $\mathrm{H}_{2} \mathrm{SO}_{4}$ solutions by anion exchange mechanism.

Olanipekun [5] reported that $99 \%$ of chromium can be recovered from Ilmenite il ores dissolved in sulfuric acid by $\overline{T O A}$.

Tri-n-octylphosphine oxide $(\overline{T O P O})$ is highly selective and an effective extractant of chromium (VI) [6,7]. The equilibria for the extraction of $\mathrm{Cr}$ (VI) from aqueous solutions of sulfuric acid with $\overline{T O P O} /$ kerosene have been studied by Huang [8], he found that the predominate species extracted into the organic phase were $\overline{\mathrm{H}_{2} \mathrm{CrO}_{4} \cdot(\mathrm{TOPO})}$ and $\overline{\mathrm{H}_{2} \mathrm{Cr}_{2} \mathrm{O}_{7} .(\mathrm{TOPO})_{3}}$.

In the present paper, the extraction of chromium (VI) from sulfuric acid solutions, by tri-n-dodecylamine $(\overline{T D A}) /$ kerosene containing octanol-1 as a modifier, as well as tri-nbutylphosphate $(\overline{T B P}) /$ kerosene, tri-n-octylphosphine oxide/kerosene and their mixtures $(\overline{T D A}+\overline{T B P} /$ kerosene, 


\begin{tabular}{|c|c|}
\hline & The upper line refers to the organic phase. \\
\hline M & Concentration in $\mathrm{mol} / \mathrm{L}$. \\
\hline$\left[\mathrm{H}_{2} \mathrm{SO}_{4}\right]_{i}$ & Initial sulfuric acid concentration in the aqueous phase (M). \\
\hline$\left[\mathrm{H}_{2} \mathrm{SO}_{4}\right]$ & Equilibrium sulfuric acid concentration in the aqueous phase (M). \\
\hline$[C r(V I)]_{i}$ & Initial chromium(VI) concentration in the aqueous phase (M). \\
\hline$[C r(V I)]$ & Equilibrium chromium( $\mathrm{VI})$ concentration in the aqueous phase $(\mathrm{M})$. \\
\hline$\overline{[C r(V I)]}$ & Equilibrium chromium(VI) concentration in the organic phase (M). \\
\hline${\overline{[C r(V I)]_{i}}}_{i}$ & Initial concentration of chromium (VI) in the organic phase (M). \\
\hline$Y_{C r(V I)} \%$ & Chromium (VI) extraction yield. \\
\hline$Y^{\prime} C r(V I) \%$ & Chromium (VI) stripping yield. \\
\hline$\overline{[T D A}_{i}$ & Initial tri-n-dodecyl amine concentration (M). \\
\hline$\overline{[T D A]}$ & Equilibrium concentration of tri-n-dodecylamine (M). \\
\hline$\overline{[T B P}_{i}$ & Initial tri-n-butyl phosphate concentration (M). \\
\hline$\overline{[T O P O}_{i}$ & Initial tri-n-octylphosphine oxide concentration (M). \\
\hline$V_{\text {org }}$ & Volume of organic phase. \\
\hline$V_{a q}$ & Volume of aqueous phase. \\
\hline$\overline{\left[\left(\mathrm{TDAH}_{2} \mathrm{SO}_{4}\right]\right.}$ & Concentration of $(\mathrm{TDAH})_{2} \mathrm{SO}_{4}$ species in the organic phase (M). \\
\hline$\left.\overline{\left[\mathrm{TDAHHSO}_{4}\right.}\right]$ & Concentration of $\mathrm{TDAHHSO}_{4}$ species in the organic phase (M). \\
\hline$\left[H^{+}\right]$ & Concentration of $\left[\mathrm{H}^{+}\right]$in the aqueous phase $(\mathrm{M})$. \\
\hline$K_{d}$ & Is the distribution coefficient $=\overline{[C r(V I)]} /[C r(V I)]$. \\
\hline$K_{d}$ & $=\overline{[C r(V I)]} /\left[C r_{2} O_{7}^{2-}\right]$ \\
\hline$K_{1}$ & Equilibrium constant of equation (15) $(\mathrm{L} / \mathrm{mol})^{4}$. \\
\hline $\mathrm{K}_{2}$ & Equilibrium constant of equation (16) (L/mol). \\
\hline $\mathrm{K}_{e x}$ & Equilibrium constant of equation (23). \\
\hline
\end{tabular}

$\overline{T D A}+\overline{T O P O} /$ kerosene), has been investigated. The stripping of $\mathrm{Cr}(\mathrm{VI})$ from the loaded organic phase $\overline{T D A} /$ kerosene with $\mathrm{Na}_{2} \mathrm{CO}_{3}$ has been carried out.

\section{Experimental}

Tri-n-dodecylamine $(\overline{T D A})$ used as an extractant was from MERCK with a purity of $95 \%$. The diluent used was the kerosene PEMCO SOLV 110 from PEMCO Chemicals company, which has a density of $800-810 \mathrm{~kg} / \mathrm{m}^{3}$ at $15^{\circ} \mathrm{C}$, its boiling point range is $200-250{ }^{\circ} \mathrm{C}$, and flash point $>70{ }^{\circ} \mathrm{C}$, with aromatic content of max $0.5 \%(\mathrm{v} / \mathrm{v})$. Octanol-1 used as a modifier was from MERCK with purity of $96 \%$.

Potassium dichromate $\left(\mathrm{K}_{2} \mathrm{Cr}_{2} \mathrm{O}_{7}\right)$ was from RIEDEL-De HAËN, with purity of $99.5 \%$.

The aqueous solutions of sulfuric acid for the preequilibration of the organic phases were prepared by diluting concentrated sulfuric acid (from FLUKA, 95-97\%) with double distilled water.

The aqueous solutions of chromium(VI) containing sulfuric acid was prepared by dissolving the necessary amount of $\mathrm{K}_{2} \mathrm{Cr}_{2} \mathrm{O}_{7}$ and concentrated $\mathrm{H}_{2} \mathrm{SO}_{4}$ in double distilled water.

The organic phases were prepared by dissolving the necessary amount of tri-n-dodecylamine and octanol-1 in kerosene, then equilibrated with sulfuric acid solution of the same concentration as the solution from which chromium(VI) was extracted.

The extraction was carried out by stirring equal volumes ( 25 $\mathrm{mL}$ ) of aqueous and pre-equilibrated organic phases at the acidity wanted in a thermostated water bath and in dark bottles to prevent any reduction of chromium(VI) to chromium(III); the mixtures were allowed to settle for $30 \mathrm{~min}$, then the two phases were separated.

The distribution coefficient $\left(\mathrm{K}_{d}\right)$, was calculated as the ratio:

$$
K_{d}=\overline{[C r(V I)]} /[C r(V I)]
$$

Where: $\overline{[C r(V I)]}$ and $[C r(V I)]$ are the total chromium concentrations in the organic and aqueous phases after equilibration, respectively.

The concentration of sulfuric acid in the aqueous phase was determined by titration with $0.1 \mathrm{~N}$ sodium hydroxide using an automatic potentiometric titrator (AT-420N-WIN) from KYOTO ELECTRONICS, Japan.

Chromium (VI) was determined in the aqueous phases spectrophotometrically using diphenylcarbazide method [9], while chromium concentration in the organic phases was calculated from the difference in the chromium (VI) content in the aqueous phase before and after extraction.

\section{Results and Discussion}

\subsection{Mixing time effect}

Equal volumes $(25 \mathrm{~mL})$ of $0.025 \mathrm{M} \overline{T D A} /$ kerosene $+10 \%$ octanol-1 and $0.1 \mathrm{M}$ sulfuric acid containing $1.923 .10^{-2} \mathrm{M}$ of $\mathrm{Cr}(\mathrm{VI})$ were mixed together at $25{ }^{\circ} \mathrm{C}$ and at organic to aqueous phase ratio $V_{o r g} / V_{a q}=1$ for various time intervals. Fig. 1 shows the variation of the distribution coefficient of $\mathrm{Cr}(\mathrm{VI})$ against time. It is clear that 1 minute is the minimum time to reach the equilibrium. 


\subsection{Effect of chromium(VI) concentration on chromium(VI)} extraction.

The extraction of chromium(VI) in the range of (0.019$0.135 \mathrm{M}$ ) by $0.1 \mathrm{M}$ tri-n-dodecylamine/kerosene containing $10 \%$ octanol-1 as modifier at an organic to aqueous phase ratio $\left(V_{\text {org }} / V_{a q}=1\right)$, and at $25{ }^{\circ} \mathrm{C}$ was examined. The results are shown in Fig. 2. The concentration of chromium(VI) in the organic phase increases with increasing the concentration of chromium(VI) in the aqueous phase.

3.3 Effect of $\mathrm{H}_{2} \mathrm{SO}_{4}$ and $\mathrm{Na}_{2} \mathrm{SO}_{4}$ concentrations on chromium( $\mathrm{VI})$ extraction

The extraction of $1.923 .10^{-2} \mathrm{M}$ chromium (VI) from different concentrations of sulfuric acid within the range $0-2 \mathrm{M}$ by 0.025 $\mathrm{M} \overline{T D A} /$ kerosene containing $10 \%$ octanol- 1 has been studied at $25{ }^{\circ} \mathrm{C}$ and at organic to aqueous phase ratio $\mathrm{V}_{\text {org }} / \mathrm{V}_{a q}=1$. The results are presented in Fig. 3.a in the form of $\log \mathrm{K}_{d}$ against $\log \left[\mathrm{H}_{2} \mathrm{SO}_{4}\right]_{i}$.

It is clear that chromium(VI) extraction increases with increasing sulfuric acid concentration until $1 \mathrm{M}$, after that the chromium(VI) extraction decreases due to the competition between $\mathrm{H}_{2} \mathrm{SO}_{4}$ and $\mathrm{Cr}(\mathrm{VI})$.

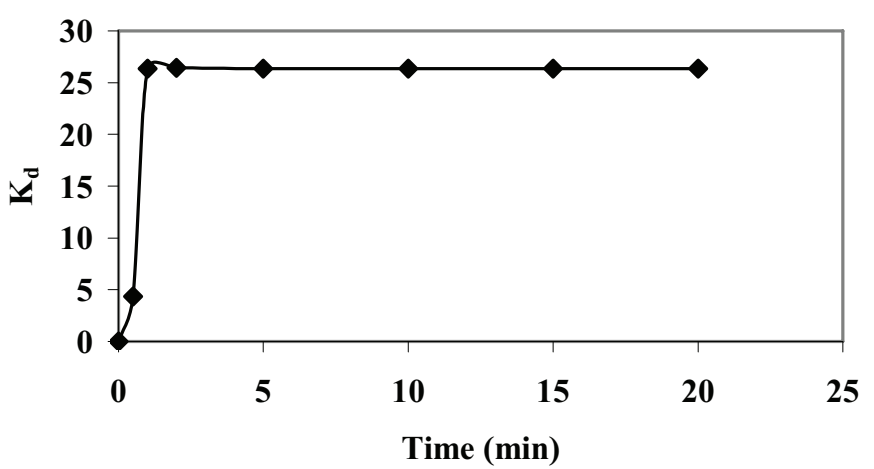

Fig. 1. Effect of time on chromium (VI) extraction. $\overline{[T D A}_{i}=0.025 \mathrm{M} /$ kerosene $+10 \mathrm{v} / \mathrm{v} \%$ octanol $-1,[\mathrm{Cr}(\mathrm{VI})]_{i}=$ $1.923 .10^{-2} \mathrm{M} .\left[\mathrm{H}_{2} \mathrm{SO}_{4}\right]_{i}=0.1 \mathrm{M}, V_{\text {org }} / V_{a q}=1, t=25^{\circ} \mathrm{C}$.

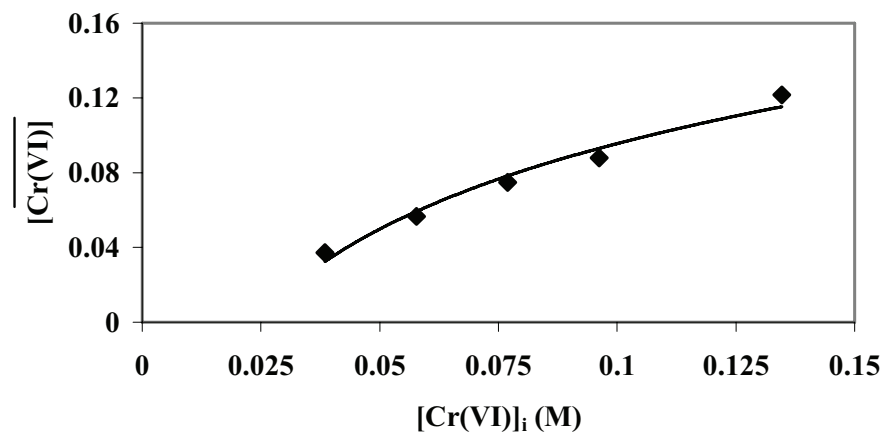

Fig. 2. Variation of chromium(VI) concentration in the organic phase vs. chromium(VI) concentration in the aqueous phase. $\overline{[T D A}_{i}=0.025$ $\mathrm{M} /$ kerosene $+10 \mathrm{v} / \mathrm{v} \%$ octanol-1, $[\mathrm{Cr}(\mathrm{VI})]_{i}=$ from 0.019 to $0.135 \mathrm{M} .\left[\mathrm{H}_{2} \mathrm{SO}_{4}\right]_{i}$ $=0.1 \mathrm{M}, \mathrm{V}_{\text {org }} / \mathrm{V}_{a q}=1, \mathrm{t}=25^{\circ} \mathrm{C}$.

The effect of sodium sulfate concentration, in the range of (0.01-1M) on the extraction of $1.923 .10^{-2} \mathrm{M}$ chromium (VI), at

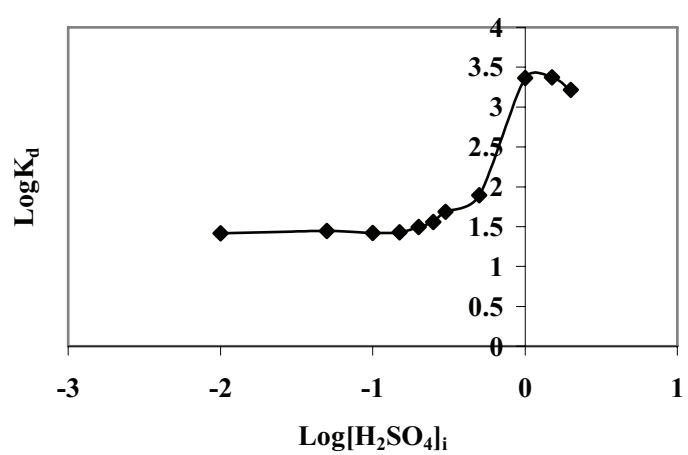

Fig. 3.a. Effect of sulfuric acid concentration on chromium(VI) extraction. $\overline{[T D A}_{i}=0.025 \mathrm{M} /$ kerosene $+10 \%$ octanol $-1,[\mathrm{Cr}(\mathrm{VI})]_{i}=1.923 .10^{-2} \mathrm{M}$. $\left[\mathrm{H}_{2} \mathrm{SO}_{4}\right]=$ from 0 to $2 \mathrm{M}$. $\mathrm{V}_{\text {org }} / \mathrm{V}_{a q}=1, \mathrm{t}=25^{\circ} \mathrm{C}$.

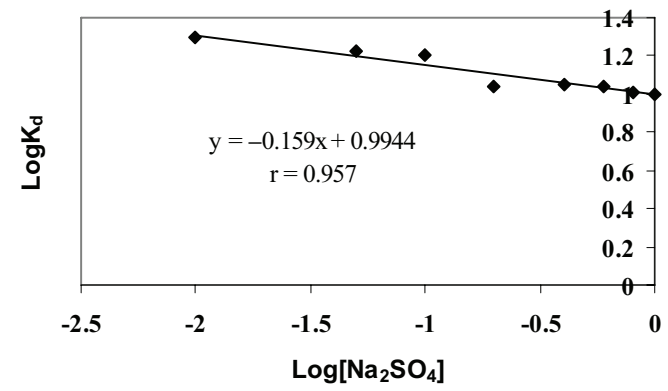

Fig. 3.b. Effect of sodium sulfate concentration on chromium(VI) extraction. $\overline{[T D A]_{i}}=0.025 \mathrm{M} /$ kerosene $+10 \%$ octanol- $1,[\mathrm{Cr}(\mathrm{VI})]_{i}$ $=1.923 .10^{-2} \mathrm{M} .\left[\mathrm{H}_{2} \mathrm{SO}_{4}\right]=0.1 \mathrm{M},\left[\mathrm{Na}_{2} \mathrm{SO}_{4}\right]=0-1 \mathrm{M}, V_{\text {org }} / V_{\text {aq }}=1, \mathrm{t}$ $=25^{\circ} \mathrm{C}$.

$\left[\mathrm{H}_{2} \mathrm{SO}_{4}\right]_{i}=0.1 \mathrm{M}$ by $0.025 \mathrm{M} \overline{T D A} /$ kerosene containing $10 \%$ octanol- 1 has been carried out, at $25{ }^{\circ} \mathrm{C}$ and at organic to aqueous phase ratio $\mathrm{V}_{\text {org }} / \mathrm{V}_{a q}=1$, the results are presented in Fig. 3.b in the form of $\log \mathrm{K}_{d}$ against $\log \left[\mathrm{Na}_{2} \mathrm{SO}_{4}\right] i$ concentration in the aqueous phase. It has been found that the presence of $\mathrm{Na}_{2} \mathrm{SO}_{4}$ in the aqueous phase accelerate the separation between the two phases after the extraction process, but the distribution coefficient of $\mathrm{Cr}(\mathrm{VI})$ decreases with increasing $\mathrm{Na}_{2} \mathrm{SO}_{4}$ in the aqueous phase, this decrease could be attributed to the formation of $\mathrm{CrSO}_{7}^{2-}$ species in the aqueous phase.

\subsection{Effect of tri-n-dodecylamine concentration on chromium(VI) extraction}

The extraction of $1.923 .10^{-2} \mathrm{M}$ chromium(VI) from $0.25 \mathrm{M}$ sulfuric acid solution by previously pre-equilibrated $\overline{T D A}$ /kerosene containing $10 \%$ octanol-1 within the range $0.025-0.35 \mathrm{M}$ at the same acidity was studied at $25^{\circ} \mathrm{C}$ and at an organic to aqueous phase ratio $\left(\mathrm{V}_{\text {org }} / \mathrm{V}_{a q}=1\right)$. The results are presented in Fig. 4 in the form of $\log \mathrm{K}_{d}$ against $\log \overline{[T D A]}_{i}$.

Fig. 4 4 shows that the distribution coefficient of chromium (VI) increases with increasing initial $\overline{T D A}$ concentration in the organic phase.

\subsubsection{Mechanism of chromium(VI) extraction by $\overline{T D A}$}

First, tri-n-dodecylamine reacts with sulfuric acid to form amine sulfate and amine bisulfate salts as described in the two following equations [10]: 


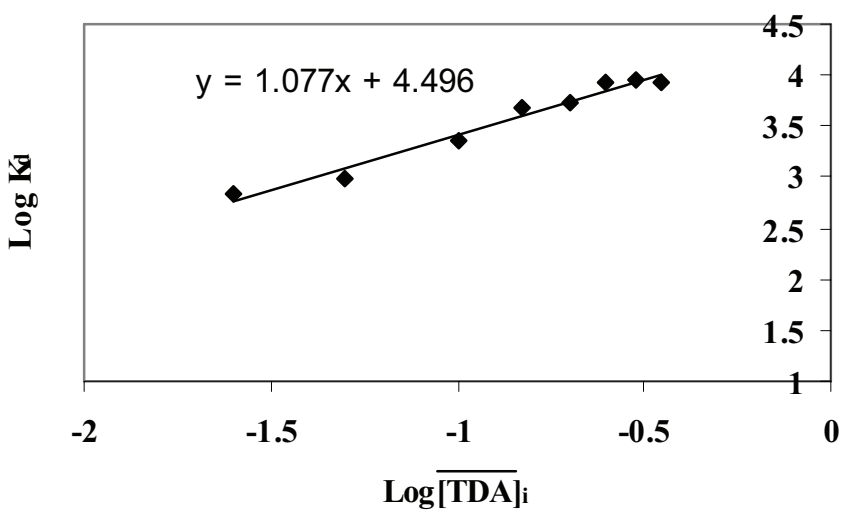

Fig. 4. Variation of $\log \mathrm{K}_{d}$ vs. $\log \overline{[T D A}_{i}, \overline{[T D A}_{i}=(0.025-0.35 \mathrm{M})$ $/$ kerosene $+10 \%$ octanol- $1,[\mathrm{Cr}(\mathrm{VI})]_{i}=1.923 .10^{-2} \mathrm{M} .\left[\mathrm{H}_{2} \mathrm{SO}_{4}\right]=0.25 \mathrm{M}$, $\mathrm{V}_{\text {org }} / \mathrm{V}_{a q}=1, \mathrm{t}=25^{\circ} \mathrm{C}$.

$2 \overline{T D A}+2 \mathrm{H}^{+}+\mathrm{SO}_{4}^{2-} \stackrel{K_{1}}{\rightleftarrows} \overline{(T D A H)_{2} \mathrm{SO}_{4}}$

$$
K_{1}=10^{9.642} l^{4} / \mathrm{mol}^{4}
$$

$$
\begin{array}{r}
\overline{(T D A H)_{2} \mathrm{SO}_{4}}+\mathrm{H}^{+}+\mathrm{HSO}_{4}^{-} \stackrel{K_{1}}{\rightleftarrows} 2 \overline{\text { TDAH HSO }_{4}} \\
K_{2}=10^{-0.899} 1 / \mathrm{mol}
\end{array}
$$

Then, dichromate ions can be extracted by anion exchange reaction with $\overline{\mathrm{TDAHHSO}_{4}}$. The extraction mechanism of chromium(VI) by tri-n-dodecylamine can be expressed as follows:

$$
\begin{aligned}
& n \overline{\text { DAHHSO}_{4}}+\mathrm{Cr}_{2} \mathrm{O}_{7}^{2-} \rightleftarrows \\
& \overline{(\mathrm{TDAH})_{2} \mathrm{Cr}_{2} \mathrm{O}_{7} .(\mathrm{n}-2) \mathrm{TDAHHSO}_{4}}+2 \mathrm{HSO}_{4}^{-}
\end{aligned}
$$

The equilibrium constant of Eq. 5 can be written as:

$$
K_{e x}=\frac{\left.\overline{\left[(T D A H)_{2} \mathrm{Cr}_{2} \mathrm{O}_{7 .}(n-2) T D A H \mathrm{HSO}_{4}\right.}\right]\left[\mathrm{HSO}_{4}^{-}\right]^{2}}{\left[\mathrm{Cr}_{2} \mathrm{O}_{7}^{2-}\right] \overline{\left[T D A H \mathrm{HSO}_{4}\right]^{n}}}
$$

Since:

$$
\left[\overline{(T D A H)_{2} \mathrm{Cr}_{2} \mathrm{O}_{7} \cdot(n-2) T D A H \mathrm{HSO}_{4}}\right]=\overline{[C r(V I)]} /,
$$

the Eq. 6becomes:

$$
K_{e x}=\frac{\frac{\overline{[\mathrm{Cr}(V I)]}}{2} \cdot\left[\mathrm{HSO}_{4}^{-}\right]^{2}}{\left[\mathrm{Cr}_{2} O_{7}^{2-}\right]\left[\overline{\left.T^{2} D A \mathrm{HSO}_{4}\right]^{n}}\right.}
$$

We denote $\mathrm{K}_{d^{*}}=\overline{[\mathrm{Cr}(V I)]} /\left[\mathrm{Cr}_{2} \mathrm{O}_{7}^{2-}\right]$.

Rearrangement and taking the logarithm of both sides of Eq.7 gives:

$$
\begin{aligned}
& \log \mathrm{K}_{d^{*}}=\log 2+\log \mathrm{K}_{e x}-2 \log \left[\mathrm{HSO}_{4}^{-}\right]+ \\
& n \log \overline{\left[T D A H \mathrm{HSO}_{4}\right]}
\end{aligned}
$$

The Log-Log plot of $\mathrm{K}_{d^{*}}$ against $\overline{\left[T D A H \mathrm{HSO}_{4}\right]}$ gives a straight line with a good correlation coefficient of 0.95 and a

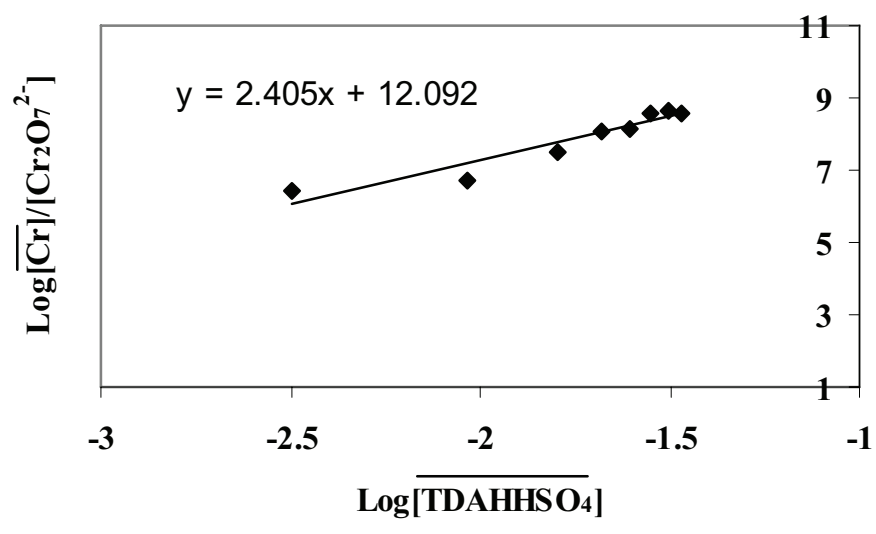

Fig. 5. Variation of $\log \mathrm{K}_{d}$ 'vs. $\left.\left.\log \overline{\left[\mathrm{TDAHHSO}_{4}\right.}\right] . \overline{[T D A}\right]_{i}=$ $(0.025-0.35 \mathrm{M}) /$ kerosene $+10 \%$ octanol- $1,[\mathrm{Cr}(\mathrm{VI})]_{i}=1.923 \cdot 10^{-2} \mathrm{M} .\left[\mathrm{H}_{2} \mathrm{SO}_{4}\right]$ $=0.25 \mathrm{M}, V_{\text {org }} / V_{a q}=1, t=25^{\circ} \mathrm{C}$.

slope equal to $=2.4$ (Fig. 5). Consequently, the extraction mechanism of chromium(VI) with tri-n-dodecylamine can be written as:

$$
2 \overline{\mathrm{TDAHHSO}_{4}}+\mathrm{Cr}_{2} \mathrm{O}_{7}^{2-} \rightleftarrows \overline{\left(\mathrm{TDAH}_{2} \mathrm{Cr}_{2} \mathrm{O}_{7}\right.}+2 \mathrm{HSO}_{4}^{-}
$$

The $\log K_{e x}$ was calculated from the intercept, and found to be 10.55 .

\subsection{Effect of temperature on chromium(VI) extraction}

The extraction of $1.923 .10^{-2} \mathrm{M}$ chromium (VI) from 0.1 M sulfuric acid by previously pre-equilibrated $\overline{T D A} /$ kerosene $+10 \%$ octanol-1 with $0.1 \mathrm{M}$ sulfuric acid within the temperature range $25-45{ }^{\circ} \mathrm{C}$ and at the organic to aqueous phase ratio $\left(\mathrm{V}_{\text {org }} / \mathrm{V}_{a q}=1\right)$ has been studied. The results are presented in Fig. 6 in the form of $\mathrm{K}_{d}$ against temperature $\left({ }^{\circ} \mathrm{C}\right)$.

From Fig. 6 it can be seen that the distribution coefficient of chromium (VI) increases with increasing the temperature, it means that the extraction reaction of chromium (VI) by $\overline{T D A} /$ kerosene is endothermic.

3.6 Effect of organic to aqueous phase ratio $V_{\text {org }} / V_{a q}$ on chromium( $\mathrm{VI})$ extraction

To select the best phase ratio for chromium (VI) extraction, the extraction of $1.923 .10^{-2} \mathrm{M}$ chromium (VI) from $0.1 \mathrm{M}$ sulfuric acid by previously pre-equilibrated $\overline{T D A} /$ kerosene $+10 \%$ octanol- 1 has been performed at $25^{\circ} \mathrm{C}$, and at different organic to aqueous phase ratios within the range $0.5-3$.

The results are presented in Fig. 7 in the form of $\%$ of chromium (VI) extracted against $\mathrm{V}_{\text {org }} / \mathrm{V}_{a q}$ phase ratio. It is obvious that chromium (VI) extraction yield $\mathrm{Y}_{\mathrm{Cr}(\mathrm{VI})}$ increases with increasing organic to aqueous phase ratio.

Whatever the phase ratio studied the yield of chromium (VI) extraction is over 95\%. In practical and economical point of view we prefer working at $\mathrm{V}_{\text {org }} / \mathrm{V}_{a q}=1$ where the mixing of the two phases is excellent and no much extractant will be used at this phase ratio. At low phase ratio $\mathrm{V}_{\text {org }} / \mathrm{V}_{a q}=0.5$ the separation of organic phase from the aqueous phase after the extraction 
process is very difficult and takes long time. While at phase ratio $\geq 1.5$ more extractant will be lost by entrainment.

\subsection{Effect of tri-n-butyl phosphate and tri-n-octylphosphine} oxide concentration on chromium(VI) extraction

The extraction of $1.923 .10^{-2} \mathrm{M}$ chromium(VI) has been studied from $0.1 \mathrm{M}$ sulfuric acid solution by different concentrations of $\overline{T B P}, \overline{T O P O}, \overline{T D A}+\overline{T B P}$ and $\overline{T D A}+\overline{T O P O}$ in kerosene pre-equilibrated with sulfuric acid solution of the same concentration as the solution from which chromium(VI) was extracted, at $25{ }^{\circ} \mathrm{C}$ and at an organic to aqueous phase ratio $\left(\mathrm{V}_{\text {org }} / \mathrm{V}_{a q}=\right.$ 1). The results are presented in Fig. 8 in the form of $K_{d}$ against initial concentration of $\overline{T B P}$ and $\overline{T O P O}$ in the organic phase with presence and non presence of $\overline{T D A}$.

Fig. 8 shows that the percentage of chromium(VI) extraction by $\overline{T B P}$ alone (curve a) is very low and did not exceed $5 \%$ at $0.4 \mathrm{M} \overline{T B P} /$ kerosene. While $\overline{T O P O}$ is very promising extractant to recover chromium(VI) from sulfuric acid solutions, since the extraction of chromium(VI) is approximately $99 \%$ at $\overline{[T O P O}]_{i}=0.4 \mathrm{M}$ (curve c).

From Fig. 8 (curve b) it can be seen that $\overline{T B P}$ has a synergistic effect when is added to $\overline{T D A} /$ kerosene at low concentration $\overline{[T B P}_{i} \leq 0.05 \mathrm{M}$, after $0.05 \mathrm{M}$ an antagonistic effect appears and the distribution coefficient of chromium(VI) decreases. $\overline{\text { TOPO }}$ always shows a synergistic effect when is added to $\overline{T D A} /$ kerosene and the distribution coefficient of chromium(VI) increases with increasing $\overline{T O P O}$ concentration in the organic phase (curve d).

\subsection{Stripping of Chromium(VI) from $\overline{T D A} /$ kerosene by sodium carbonate}

The organic phase $\overline{T D A} /$ kerosene containing $10 \%$ octanol-1 has been loaded with chromium (VI) by extracting $1.859 .10^{-2}$ $\mathrm{M}$ chromium (VI) from $0.1 \mathrm{M}$ sulfuric acid at $25{ }^{\circ} \mathrm{C}$ and at an organic to aqueous phase ratio of $1: 1$. The loaded organic phase which contains $1.785 .10^{-2} \mathrm{M}$ chromium (VI) was stripped with $(0,0.01,0.05,0.1,0.25,0.5 \mathrm{M})$ sodium carbonate at $25{ }^{\circ} \mathrm{C}$ and at an organic to aqueous phase ratio of 1:1. Fig. 9 illustrates the effect of sodium carbonate concentration on the yield of chromium (VI) stripping $\left(\mathrm{Y}^{\prime} \operatorname{Cr}(V I)\right)$. The results show that the yield of chromium (VI) stripping increases with increasing $\mathrm{Na}_{2} \mathrm{CO}_{3}$ concentration to reach the yield $\sim 70 \%$ for $0.05 \mathrm{M}$ sodium carbonate after this concentration no significant change of $\mathrm{Y}^{\prime} \mathrm{Cr}(\mathrm{VI})$ has been observed. It is very important to note that the stripping of chromium (VI) with sodium carbonate $\geq 0.1 \mathrm{M}$ form an emulsion and the separation between the aqueous and organic phase becomes very difficult and needs to be centrifuged, so it is advised to run the stripping operation at $0.05 \mathrm{M}$ sodium carbonate in two stages to avoid the formation of the emulsion and to strip completely chromium (VI) from the organic phase.

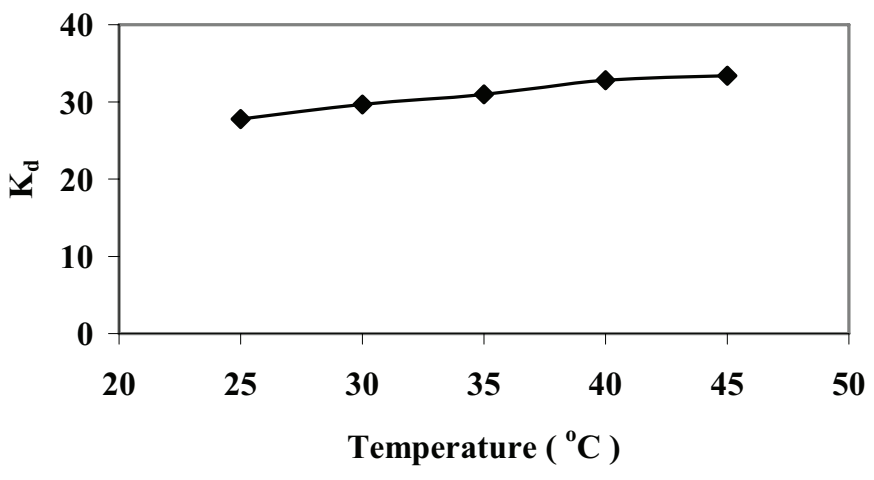

Fig. 6. Effect of temperature on chromium(VI) extraction. $\overline{[T D A}_{i}=$ $0.025 \mathrm{M} /$ kerosene $+10 \mathrm{v} / \mathrm{v} \%$ octanol,$[\mathrm{Cr}(\mathrm{VI})]_{i}=1.923 .10^{-2} \mathrm{M} .\left[\mathrm{H}_{2} \mathrm{SO}_{4}\right]=$ $0.1 \mathrm{M}, V_{\text {org }} / V_{a q}=1, t=25-45^{\circ} \mathrm{C}$.

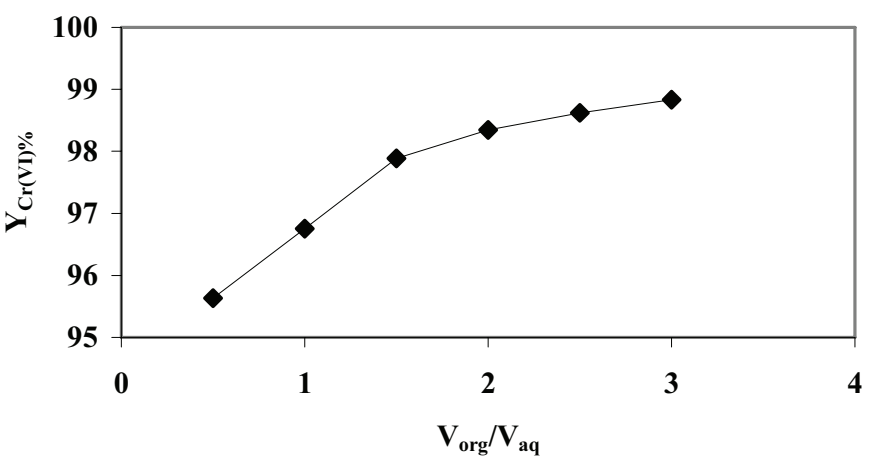

Fig. 7. Effect of organic to aqueous phase ratio $\mathrm{V}_{\text {org }} / \mathrm{V}_{a q}$ on chromium(VI) extraction. $\quad \overline{[T D A}_{i}=0.025 \mathrm{M} /$ kerosene+ $10 \%$ octanol $-1, \quad[\mathrm{Cr}(\mathrm{VI})]_{i}=$ $1.923 .10^{-2}$ M. $\left[\mathrm{H}_{2} \mathrm{SO}_{4}\right]=0.1 \mathrm{M}, V_{\text {org }} / V_{a q}=0.5,1,1.5,2,2.5,3 . t=25$ ${ }^{\circ} \mathrm{C}$.

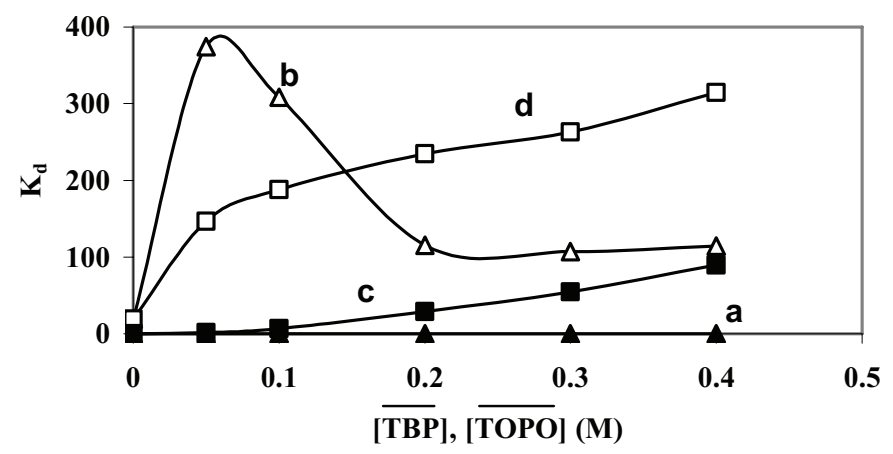

Fig. 8. Effect of $\overline{T B P}$ and $\overline{T O P O}$ percentages on chromium(VI) extraction. $[\mathrm{Cr}(\mathrm{VI})]_{i}=1.923 .10^{-2} \mathrm{M},\left[\mathrm{H}_{2} \mathrm{SO}_{4}\right]=0.1 \mathrm{M}, \mathrm{V}_{\text {org }} / \mathrm{V}_{a q}=1, \mathrm{t}=25^{\circ} \mathrm{C}$. a: $\overline{T B P}$ alone (from $0-0.4 \mathrm{M} \overline{T B P} /$ kerosene). b: $0.025 \mathrm{M} \overline{T D A}+10 \%$ octanol-1 + (0-0.4 $\mathrm{M} \overline{T B P} /$ kerosene). c: $\overline{T O P O}$ alone (from 0-0.4 M $\overline{T O P O} /$ kerosene). d: $0.025 \mathrm{M} \overline{T D A}+10 \%$ octanol- $1+(0-0.4 \mathrm{M} \overline{T O P O} /$ kerosene $)$. 


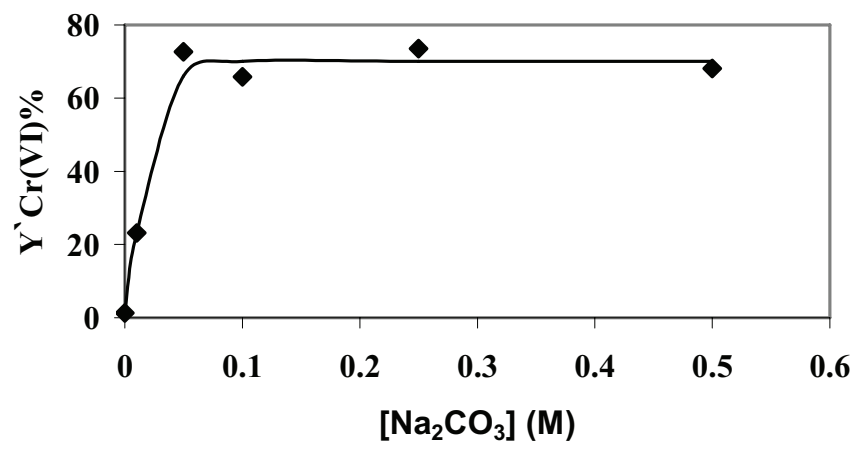

Fig. 9. Stripping of Chromium(VI) from the organic phase $0.025 \mathrm{M} \overrightarrow{T D A}$ $+10 \%$ octanol-1 by sodium carbonate. $\overline{[\mathrm{Cr}(\mathrm{VI})]_{i}}=1.785 .10^{-2} \mathrm{M}$, $\left[\mathrm{Na}_{2} \mathrm{CO}_{3}\right]_{i}=0,0.01,0.05,0.1,0.25,0.5 \mathrm{M}$. $V_{\text {org }} / V_{a q}=1, t=25^{\circ} \mathrm{C}$.

\section{Conclusion}

The extraction of Chromium(VI) by $\overline{T D A} /$ kerosene containing octanol-1 as a modifier has been studied and found to be simple, effective, and more than $95 \%$ of chromium (VI) can be extracted in one stage, then chromium (VI) can be completely stripped in two stages from the organic phase by 0.05 $\mathrm{M} \mathrm{Na} \mathrm{CO}_{3}$.

The acidity of the aqueous phase has a positive effect on chromium (VI) extraction until $1 \mathrm{M}$ after that the extraction of chromium (VI) decreases because of the competition between sulfuric acid and chromium (VI).

The presence of $\mathrm{Na}_{2} \mathrm{SO}_{4}$ in the aqueous phase has a negative effect on chromium(VI) extraction, nevertheless the addition of a very small amount of $\mathrm{Na}_{2} \mathrm{SO}_{4}$ to the aqueous phase will reduce the time of separation between the aqueous and organic phases.

The temperature has a positive effect on chromium (VI) extraction, by $\overline{T D A} /$ kerosene, and accelerates the separation between the aqueous and the organic phases during the settlement.

The extraction mechanism of chromium(VI) by tri-ndodecylamine containg octanol-1 can be expressed as follows:

$$
2 \overline{T D A H \mathrm{HSO}_{4}}+\mathrm{Cr}_{2} \mathrm{O}_{7}^{2-} \rightleftarrows \overline{(T D A H)_{2} \mathrm{Cr}_{2} \mathrm{O}_{7}}+2 \mathrm{HSO}_{4}^{-}
$$

The logarithm of equilibrium constant of this equation was calculated and found to be 10.55 .

Tri-n-butyl phosphate plays a synergistic effect at low concentration ${\overline{[T B P]_{i}}}_{i} \leq 0.05 \mathrm{M}$ when it is added to the organic phase $\overline{T D A}$ /kerosene, while $\overline{T O P O}$ always shows a synergistic effect when it is added to $\overline{T D A}$ /kerosene.

\section{References}

1 J. Rose, Environmental Toxicology, Current Developments, Gordon and Breach Science Publishers, Japan, 1998.

2 Guertin J, Jacobes JA, Avakian CP, Chromium(VI) handbook, CRC Press, Boca Raton, Florida, 2005.

3 C. Deptula, J. Inorg. Nucl. Chem 30 (1968), 1309-1316.

4 Fedorov IA, Zhdanov YF, Zh. Neorg. Khim 13 (1968), no. 8, 2227-2229.

Olanipekun EO, Bull. Chem. Soc. Ethiop. 14 (2000), no. 2, 115-121.

6 A. Ohki, Y. Fujino, K. Ohmori, M. Takagi, Solvent Extraction and Ion Exchange. 4 (1986), no. 4, 639.
7 J. C. White, W. J. Ross, Extraction of chromium with trioctylphosphine oxide, 1957.

8 Ting-Chia Huang, Chee-Chang Huang, Dong-Hwang Chen, Solvent extraction and ion exchange 5 (1997), 837-862.

9 E. Tütem, K. Sözgen, E. Baracan, Analytical Sciences 17 (2001), 857860. supplement.

$10 \mathrm{~J}$. Stas, Liquid-Liquid extraction of sulfuric acid using tri-ndodecylamine/kerosene, Periodica Polytechnica. Ser. Chem. Eng. under publication. 